\title{
Revista de Medicina of the University of São Paulo School of Medicine: the centennial reflects excellence!
}

I is undeniable that, among all the needs and rights of citizens, education, dissemination of knowledge, scientific production and the stimulation of critical skills are the greatest assets one can accumulate and offer; Thus, the entire Nation's greatest duty is to grow and develop itself.

The University of São Paulo, which places Brazil in a prominent position with regard to higher education and includes a select group of world-class institutions, accounts for $22 \%$ of the scientific production in the country.

Dissemination of this knowledge produced by the Academy in this year of 2016 assumes a fundamental outline: the centennial of the University of São Paulo's School of Medicine distinguished Revista de Medicina, which symbolizes the commitment and responsibility for education and all that can be generated from it in evolutionary terms.

And the magnificence of the past and the contemporary, of tradition and innovation, have been translating into a considerable number of works which, beyond the theoretical aspect, bowed to the understanding of sentience and equanimity among all living beings, as they hone in studies which also favor substitutive methods for the use of animals.

Reverently, I congratulate the University of São Paulo's esteemed Revista de Medicina for this date, whose importance is proportional to the force and weight of the years that we celebrate.

\author{
José Ricardo Alvarenga Trípoli \\ Federal Deputy
}

Brazilian Social Democracy Party 


\section{Revista de Medicina da Universidade de São Paulo: o centenário traduz a excelência!}

É inegável que, dentre todas as necessidades e direitos dos cidadãos, a educação, a disseminação do conhecimento, a produção científica e o estímulo à capacidade crítica são os maiores bens que se pode acumular e ofertar, sendo dever maior de toda Nação, que tenha como escopo crescer e se desenvolver.

A Universidade de São Paulo, que coloca o Brasil em uma posição de destaque, no tocante ao ensino superior e integra um seleto grupo de instituições de padrão mundial, responde por $22 \%$ da produção científica do país.

A disseminação deste conhecimento produzido pela Academia, neste ano de 2016 assume fundamental contorno: o centenário da ilustre Revista de Medicina da Universidade de São Paulo, que simboliza o compromisso e a responsabilidade no ensino e com o que dele se pode gerar, em termos evolutivos.

E a imponência do passado e do contemporâneo, da tradição e da inovação, tem se traduzido no montante considerável de trabalhos que, para além do teórico, se curvam ao entendimento da senciência e da equanimidade entre todos os seres viventes, ao se esmerarem em estudos que também privilegiam métodos substitutivos ao uso de animais.

Com reverência, congratulo a Emérita Revista de Medicina da Universidade de São Paulo, por esta data, cuja importância é proporcional ao vigor e peso dos anos que se comemora. 